Urszula Putyńska

Uniwersytet im. Adama Mickiewicza

w Poznaniu

urszula.putynska@amu.edu.pl
Data przesłania tekstu do redakcji: 14.11.2016

Data przyjęcia tekstu do druku: 15.02.2017

\title{
Odegrać przeszłość. Szkic o powieści Götz i Meyer Davida Albahariego
}

\begin{abstract}
Putyńska Urszula, Odegrać przeszłość. Szkic o powieści Götz i Meyer Davida Albahariego (Reenacting the Past. An Essay on Götz and Meyer by David Albahari). "Poznańskie Studia Slawistyczne" 12. Poznań 2017. Publishing House of the Poznań Society for the Advancement of the Arts and Sciences, pp. 271-282. ISSN 2084-3011.

This paper is the analysis of Götz and Meyer (Gec i Majer, 1998) by David Albahari (b. 1948), the writer of Serbian and Jewish origin. His novel belongs to the Holocaust-literature and its metanarrative structure calls into question the problem of transferring radical historic moment into fiction. The article focuses on the interrelations between fiction and fact, imagination and history, as well as the traumatic experience recognized as the opportunity to identify with the experience of Holocaust victims. Albahari's novel proves that remembering of dramatic events from the past can be activated both by imagination and traumatic experience.
\end{abstract}

KeYwords: David Albahari; Gec i Majer; literature of Holocaust; history; fiction; narrative; memory; experience; imagination; identity

Transatlantik: David Albahari - tymi słowami Aleš Debeljak tytułuje esej poświęcony serbskiemu pisarzowi w przenikliwej, a i niepozbawionej poetyckiego powabu książce Balkansko brvno. Eseji o književnosti „jugoslavenske Atlantide”. Próba deszyfracji tytułowej metafory zaprowadzi nie tylko do biografii autora - geograficznej obecności po dwóch stronach Atlantyku', ale również (i przede wszystkim) do centralnego pola jego literackich poszukiwań: penetrowania granic i warunków roz-

\footnotetext{
${ }^{1}$ David Albahari, Serb żydowskiego pochodzenia, od 1994 roku mieszka w Kanadzie (Calgary). Autor pisze po serbsku, a pierwsze wydania jego książek ukazują się w serbskich wydawnictwach.
} 
poznania/uzgodnienia własnej tożsamości. Zdaje się bowiem, że Albahari, korzystając z różnych poetyk i posługując się odmiennymi gatunkami (również zawieszając linię podziału między nimi), bada kondycję podmiotu poddanego siłom zewnętrznym (używając dużego kwantyfikatora - wydarzenia historyczne) i odśrodkowym (również ze świadomością upraszczającego uogólnienia - intymne doświadczenia jednostki), zapętlającym się właśnie w przestrzeni metaforycznego transatlantyku. Słoweński poeta, zarysowując różnice między kreacją narratora $\mathrm{w}$,,jugosłowiańskim” i „kanadyjskim” okresie twórczej działalności Albahariego, zauważa:

U kanadskim prozama tako, umjesto razglabanja o razlici između istine i izmišljenoga, pred čitateljeve oči prodire promišljanje o nezauzdanim silnicama povijesti. Umjesto raznih riječi za istu (ili nijednu) stvar sada se pripovjedač mora suočavati s pitanjima raznih identiteta, egzila i dijaspore, odnosno bitnim pitanjima moderne condition humaine (Debeljak 2014: 69)².

Serbski pisarz żydowskiego pochodzenia, którego rodzinne i osobiste losy naznaczone zostały biegiem dramatycznych wydarzeń historycznych $\mathrm{XX}$ wieku, wielokrotnie w swojej prozie konstruuje figurę labilnego wewnętrznie narratora-bohatera, kwestionując możliwość ukonstytuowania stabilnej i trwałej struktury tożsamości. Obserwację tę potwierdzają słowa autora:

Pitanje identiteta od primarne je važnosti za sve nas jer je, rekao bih, život u dobroj mjeri određen upravo mijenjanjem naših identiteta. (...) Za mene je pitanje identiteta bilo izuzetno važno u mladalačkim godinama, posebice zato što potječem iz mješovitog braka, ali onog trenutka kad sam prihvatio židovski segment svog identiteta, osjetio sam mir. Kasnije sam shvatio da je i taj mir prividan, da se identitet mora neprekidno potvrđivati, te sam na to pitanje pokušao odgovoriti svojom prozom (Ognjenović 2007: 13).

W kontekście twórczości Davida Albahariego istotną i inspirującą interpretacyjnie kwestię stanowi skomplikowana (i świadomie komplikowana) relacja: autor-narrator-bohater, ta jednak nie będzie problematyzowana

${ }^{2} \mathrm{O}$ przemianach w prozie Davida Albahariego - podobnie jak Aleš Debeljak, emigrację traktując jako cezurę zmian w pisarstwie autora - pisze Julian Kornhauser w artykule Serbska literatura emigracyjna po 1991 roku. Przypadek Davida Albahariego (Kornhauser 2009: 133-147). 
w niniejszym szkicu ${ }^{3}$. Analizując powieść Götz i Meyer (2007) ${ }^{4}$, instancję autora wyraźnie oddzielać będę od figury narratora, choć nie bez świadomości autorskiego wyznania: „(...) jedino pišući o sebi mogu da se nadam da ću opisati svet ili bar deo sveta, jer ako nema mene u tekstu, onda nema ni sveta (...)" (Albahari 2012: 22).

Przyglądając się współczesnym dziełom będącym wyrazem podejmowania prób literackiej reprezentacji Zagłady przez pisarzy, którzy dramatu przeszłych zdarzeń nie doświadczyli bezpośrednio, można zauważyć odmienne stanowiska autorów wobec możliwości i funkcji wykorzystania fikcjonalnych ram do opisu tragicznych wydarzeń historycznych. Sidra DeKoven Ezrahi, odwołując się do utworów kolejnych pokoleń piszących o Shoah, zauważa: „Z biegiem lat można (...) zaobserwować rozluźnienie lub przekształcenie związków pomiędzy wydarzeniami historycznymi a wyobraźnią literacką oraz słabnące oddziaływanie «nakazu dania świadectwa»" (DeKoven Ezrahi 2014: 273). Autorzy, etycznie zobowiązani do zachowania szacunku i pamięci wobec ofiar, oscylują między oddaniem sprawiedliwości precyzji faktograficznej a prawem do kreowania fikcyjnego świata. Newralgiczne w tym kontekście staje się pytanie, czy niepojęta - nieobecna w ramach racjonalnego wyjaśniania - ,zagładowa i zgładzona rzeczywistość" (Nycz 2012: 238) podlega reprezentacji, która miałaby przekształcić niepojmowalne doświadczenie w formę możliwą do przedstawienia (więc uobecnienia).

Do wyżej zarysowanej refleksji ściśle przystaje powieść Davida Albahariego Götz i Meyer. Serbski autor, chcąc zbliżyć się do prawdy przeszłego dramatu, skłania się w stronę fikcji - fikcyjna kreacja ma stanowić

\footnotetext{
${ }^{3}$ Miłosz Bukwalt w szkicu poświęconym powieści Götz i Meyer jej narratora określa jako porte-parole autora (Bukwalt 2014: 68). Wnikliwą analizę dotyczącą tej problematyki, w kontekście innych dzieł autora, znaleźć można w artykule Sabiny Giergiel Czy ja to mój bohater? Davida Albahariego gra rolami narracyjnymi (Giergiel 2007: 35-54).

${ }^{4}$ Podany tytuł i data dotyczą polskiego wydania powieści (cytowane z niej fragmenty są autorstwa Milana Duškova). Pierwsze wydanie powieści Gec i Majer ukazało się w Serbii w 1998 roku.
} 
kanał dostępu do historycznej przeszłości ${ }^{5}$. Gest ten ujawnia się na dwóch poziomach: w wewnętrznej warstwie tekstu - narrator, chcąc doświadczyć niezrozumiałego, wykorzystuje własną wyobraźnię, by postaci historyczne „wypełnić” wyimaginowaną egzystencją, oraz w płaszczyźnie metanarracyjnej - autor, chcąc stworzyć przestrzeń dla wyartykułowania niewyobrażalnego doświadczenia, równocześnie zadaje pytanie o możliwość przeniesienia go do świata fikcji literackiej.

\section{3.}

Bezimienny narrator powieści mierzy się z historią serbskich Żydów zamkniętą $\mathrm{w}$ archiwalnych dokumentach. Pięćdziesięcioletni mężczyzna o żydowskich korzeniach, pragnąc poznać losy swoich przodków, odkrywa prawdę o śmierci żeńskiej linii rodzinnej genealogii:

(...) prawie wszystkie kobiety z rodzin mojego ojca i mojej matki nie zginęly, jak to zwykło się mówić, w obozie na Targach: w rzeczywistości zmarły na belgradzkich ulicach i drogach, w ciężarówce, którą Götz i Meyer jeździli na miejsce straceń w miejscowości Jajinci (Albahari 2007: 15).

Wysiłek samozwańczego badacza przeszłości, którym staje się narrator, analizowanie danych dotyczących życia w obozie Sajmište oraz organizacji masowej zagłady ludności żydowskiej i romskiej w Serbii, skutkuje

${ }^{5}$ Marija Mitrović, zaznaczając podobieństwa między utworem Götz i Meyer i trzema wcześniejszymi powieściami Albahariego - Snežni čovek (1995), Mamac (1996), Mrak (1997) - widzi możliwość genologicznego przyporządkowania wszystkich czterech utworów do gatunku nowej powieści historycznej [modern historical novel] (Mitrović 2005: 83). Możliwość takiej klasyfikacji sugeruje również Sylwia Nowak-Bajcar, wskazując jednocześnie, że proza Albahariego wymyka się ramom jednoznacznego określenia gatunkowego, przy czym, według badaczki, obecność warstwy autobiograficznej i planu historycznego w utworach pisarza wynika z właściwości pisarstwa autobiograficznego: „Pisanie autobiograficzne w wydaniu Albahariego jest wskazaniem na umowność autobiograficznej konwencji. W zasadzie o genologii świadczy przesuwanie dominant: gdy narrator koncentruje się wyłącznie na własnej wypowiedzi - mamy do czynienia z powieścią autobiograficzną, kiedy zaś liczba odniesień do rzeczywistości się zwiększa, a przestrzeń utworu ukonkretnia - utwory, nie tracąc swojego autobiograficznego charakteru, wkraczają również w konwencję nowej powieści historycznej. Wraz z nakierowaniem uwagi narratora powieści na rzeczywistość zewnętrzną (...), dokonuje się w prozie Albahariego wyraźny zwrot ku referencjalności, która w powieściach emigracyjnych (wydanych po 1993 roku) uwidacznia się bardzo wyraźnie (...)” (Nowak-Bajcar 2010: 120-121). 
zderzeniem z suchą relacją historyczną (dawkowaną czytelnikowi w toku lektury): faktami, liczbami, nazwiskami. Uzyskana wiedza nie spełnia pokładanych w niej nadziei - nie umożliwia zrozumienia dramatu przodków i nie pozwala logicznie uzasadnić przeszłych zdarzeń. Narrator pozostaje wobec poznanych faktów bezsilny, nie jest zdolny wiedzy o nich anulować, ani zniwelować swojego pierwotnego, założycielskiego dla poszukiwań, niepokoju. Przeciwnie, na jego niemoc kaskadowo spadają kolejne wątpliwości, których zbiór odnalezionych informacji w żaden sposób nie rozmywa. Historia jako rezerwuar odpowiedzi na pytania o sens śmierci przodków i gotowość zwyczajnych ludzi do wspierania funkcjonowania machiny zagłady okazuje się bezwartościowa:

(...) historia jest bezbarwna i, przynajmniej jako nauka, nie może istnieć na poziomie jednostki, bo wtedy nie można by jej pojąć. Stąd każda historia sprowadza się do poszukiwania najmniejszych i największych mianowników, jakby wszyscy ludzie byli tacy sami, a wszystkie ludzkie losy jednakowe (Albahari 2007: 30).

Narrator nie pyta o porządek faktograficzny, ale o możliwość uzgodnienia tegoż porządku z porządkiem etycznym, o możliwość wyjaśnienia przeszłych wydarzeń w ramach współczesnej mu rzeczywistości, stąd rozczarowanie: „Historia nie ma czasu na uczucia, jeszcze mniej na niedowierzanie i ból, a wcale na tępą niemotę, na niemożność zrozumienia tego, co się dzieje" (Albahari 2007: 31).

Dla bohatera, pragnącego zbliżyć się do zrozumienia dramatu zamordowanych członków rodziny, konieczne staje się przeobrażenie ,„postaci historycznych" (Wilhelma Götza i Erwina Meyera), których poznanie ogranicza sucha relacja archiwalna, w „osoby rzeczywiste”, których losy ująć można w narracji. Proces ten warunkowany jest pracą wyobraźni:

Pustka, która tworzyła Götza i Meyera, stała w takim przeciwieństwie do pełni moich krewnych - jeśli nie ich rzeczywistych istot, to przynajmniej ich śmierci - że każda moja próba dotarcia do pełni wymagała przejścia przez pustkę. Chcąc naprawdę zrozumieć rzeczywistych ludzi, jakimi byli moi krewni, musiałem najpierw zrozumieć ludzi nierzeczywistych, jakimi byli Götz i Meyer. Nie: zrozumieć, ale stworzyć ich (Albahari 2007: 54).

Przyczyny konieczności przeniesienia faktów i postaci historycznych w fikcyjny świat stają się tożsame $\mathrm{z}$ determinantami fundującymi całą powieść, są nimi: próba zrozumienia $\mathrm{i}$ - w dalszej konsekwencji - potrzeba pamięci. 
4.

Narrator, nauczyciel języka serbsko-chorwackiego i literatur narodów jugosłowiańskich w belgradzkiej szkole, rekonstruuje życie obozowe ofiar nazistów i pracę dwóch niemieckich podoficerów odpowiedzialnych za śmierć około siedmiu tysięcy serbskich Żydów i Romów przewożonych przez nich ciężarówką (nazywaną „dušegupką”), opierając się na zebranych faktach i własnej wyobraźni. Narrator usiłuje urzeczywistnić postaci historyczne, uzupełniając nazwiska wyobrażonymi (ale potencjalnie możliwymi) zachowaniami, odczuciami, rozmowami. Tworzy ich fikcyjne żywoty czy raczej - odwrotnie układając akcenty - ,ufikcyjnia” (de facto - konstruuje) postaci z przeszłości, by przybliżyć je teraźniejszości, zbudować wspólną dla siebie i „wyobrażonych” płaszczyznę doświadczenia. Zadaniem tych zabiegów miałoby być doprowadzenie narratora do racjonalnego wyjaśnienia czynów niemieckich żołnierzy i zrozumienia śmierci krewnych. Cel ten jednak nie zostaje osiągnięty, dzięki czemu (na planie metanarracyjnym) autor odsłania własne wątpliwości dotyczące (etycznej) słuszności gestu ujęcia w fikcję dramatu ofiar Holokaustu. Wątpliwości wobec użytej strategii autor uwydatnia, doprowadzając w powieści do wielokrotnego dewaluowania aktu wyobraźni: wypowiedzi powołujące do życia fikcję funkcjonują w stałej możliwości zniesienia przez komunikat przeciwstawny.

Stosunek narratora do kreowanej przez niego rzeczywistości nie daje się uzgodnić, ułożyć w spójną narrację, co w bezpośredni sposób oddziałuje na proces jego samoidentyfikacji. Zdobyta w toku badań archiwaliów wiedza o historii przodków nie skutkuje scaleniem samoświadomości - poczucie bowiem własnej tożsamości pamiętającego podmiotu ufundowane jest na „braku”, co znaczy, że jego podmiotowość zawsze ugruntowana będzie na wyobrażeniu. Wiedza o życiu przodków w obozie Sajmište, rekonstruowanie momentu ich śmierci i świadomość losu pozwalają narratorowi zamazać białe plamy na rozrysowanym drzewie genealogicznym:

Moje drzewo genealogiczne już wyglądało inaczej, wypełniało się liśćmi, rozgałęziło i wzmocniło. Sądząc z obrazu, który projektowałem, powinienem mieć sześćdziesięciu siedmiu bliższych i dalszych krewnych, a miałem, jak to później stwierdziłem, tylko sześciu (Albahari 2007: 25-26). 
Wiedza, która wzmacnia drzewo, nie skutkuje jednak wzmocnieniem podstaw tożsamości. Z chwilą, gdy przychodzi świadomość „białych plam", nawet brak podjęcia poszukiwań mających na celu ich wypełnienie czy wyjaśnienie, unieważnia skomponowanie (spójnego) obrazu własnej osoby sprzed nabycia wiedzy. Dla narratora możliwość niepamięci traci aktualność. Miejsce wyboru: pamiętać - nie pamiętać, zajmuje pytanie o możliwość skonstruowania sensu własnej historii, której podstawą jest wymykająca się zrozumieniu, a oddziałująca na różnych płaszczyznach, strata. Próba jak najpełniejszego skonfrontowania się z przeszłością nie jest środkiem do odzyskania spójności wewnętrznej i komfortu psychicznego, przeciwnie, uświadomiona strata pozostawia trwałą szczelinę w podstawie tożsamości:

Spójrzcie na mnie: leżę na podłodze jak zbity pies, głowę oparłem o stos książek, gapię się w ścianę, na której nic nie ma. Leżę przyciśnięty niezliczonymi danymi, widokami ze zdjęć, opisami, szczegółami technicznymi dotyczącymi produkcji ciężarówek, liczbami, średnimi, imionami. Czuję, że zostanę tu na zawsze, nieruchomy. Już nigdy nie będę mógł wyjść (Albahari 2007: 90).

Belgradzki nauczyciel doświadcza rozpadu własnej podmiotowości, jego życie rozprasza się na kilka równoległych świadomości. Konstruowane postaci, zbliżane do własnych doświadczeń pracą wyobraźni, zaczynają egzystować, a w krytycznym momencie dominować w codzienności narratora:

Schludnie i bezboleśnie moje życie podzieliło się na trzy równoległe żywoty. Jeden nadal należał tylko do mnie: w nim rano wstawałem, goliłem się, jadłem śniadanie, szedłem do pracy (...). Drugi był żywotem stałych przemian: w nim (...) na zmianę przeistaczałem się w któregoś z moich krewnych (...). Trzeci był dwugłowy: w nim równocześnie byłem i Götzem i Meyerem, aniołem śmierci i kierowcą, żołnierzem i prostym człowiekiem, pozornym zbawcą i rzeczywistym wykonawcą wyroków. W tej plątaninie, to można łatwo stwierdzić, czasami nie wiedziałem, kim jestem (Albahari 2007: 39).

Usiłując zrekonstruować przeszłość, narrator „przemienia się” w kolejne postaci. Mężczyzna osuwa się w szaleństwo, zbliżanie do doświadczenia przodków (realizowane również w życiu codziennym - np. rezygnowanie z posiłków) oraz próba wyzyskania z niemych faktów słów, twarzy, uczuć zbrodniarzy prowadzi do stopniowego zapadania się realności. 
Bohater rezygnuje $\mathrm{z}$ obecności w aktualnej sobie rzeczywistości, oddając własną podmiotowość „urzeczywistnianym” postaciom historycznym (zarówno tym przynależnym do „wielkiej historii”, udokumentowanej, jak i krewnym obecnym w intymnej historii rodzinnej). Obezwładniony dramatem przodków i dojmującym poczuciem braku możliwości rozumowego uzasadnienia krzywdy i zła, decyduje się pamiętać. Pamięć (bardziej: pamiętanie - by podkreślić trwałość i procesualność tego gestu) unieważnia zaś możliwość skonstruowania mocnej podmiotowości. Podmiot świadomy przeszłości zostaje trwale naznaczony cierpieniem, które staje się dlań konstytutywne.

\section{5.}

Bezimienny badacz przeszłości, który - wobec niezdolności historii do wytworzenia płaszczyzny zrozumienia dramatycznych wydarzeń - skłania się w stronę fikcji, decyduje się nią posłużyć również w celu dydaktycznym. Nauczyciel organizuje wycieczkę dla swoich uczniów, której trasa odnawia drogę pokonywaną ,dušegupką” przez Götza i Meyera. Autobus wypełniony młodymi ludźmi, prowadzony przez stale gwiżdżącego, aroganckiego kierowcę, zatrzymuje się we wszystkich newralgicznych punktach ostatniej drogi, którą wraz z innymi ofiarami pokonali krewni narratora niemal pięćdziesiąt lat wcześniej. W czasie rekonstruowania wydarzeń nauczyciel odwołuje się do doświadczeń uczniów, do dostępnych im empirycznie elementów rzeczywistości. Każdemu z nich nadaje też nową tożsamość - imię i historię jednego z zamordowanych przodków:

Każdy z was, powiedziałem, teraz stanie się kimś innym, każdy stanie się najpierw imieniem, a potem osobą, której imię nosi. Zacząłem rozdawać imiona wokół siebie, jakbym rozrzucał ziarna. Chłopcy stali się moimi kuzynami, uczennice kuzynkami (Albahari 2007: 113).

W ten sposób mężczyzna „ucieleśnia straconych”, sobie zaś przydziela rolę dwunastoletniego chłopca, Adama, którego postać wymyślił. Wyimaginowany los staje się osnową całej opowieści. Jego celem jest udostępnienie uczniom przeszłej rzeczywistości dzięki ich realnemu udziałowi w przywracaniu pamięci odległych wydarzeń, przeniesieniu elementów 
przeszłości w obręb aktualnego przeżycia. Na pytanie, o czym będzie lekcja, odpowiada: „O różnicy pomiędzy rzeczywistością a dziełem sztuki (...), ale i o podobieństwie między chwilą realności a owocem wyobraźni" (Albahari 2007: 100-101). Głównym zamierzeniem potomka straconych Żydów jest przekazanie kolejnemu pokoleniu „czułej”, „egzystencjalnej” pamięci o ludziach doświadczonych przez bieg „nieczułej”, „nieludzkiej” historii ${ }^{6}$. Niepojmowalne i niewyrażalne doświadczenie Zagłady nie może zostać wyartykułowane spójną narracją, będącą gruntem pod możliwość zrozumienia, oswojenia i uzasadnienia, jednak może i powinno zostawić ślad w pamięci, a ten proces wymaga uaktywnienia bieżącego doznania. Emocje wywołane w czasie wycieczki mają szansę trwale wpisać się w osobistą pamięć uczniów, przez co dramat przeszłych wydarzeń zostanie „upamiętniony” w jednostkowej historii ich życia, uzyskując swoistą formę reprezentacji. Podczas nietypowej lekcji nauczyciel tworzy mentalną przestrzeń dla odczucia skrajnych emocji, a ci uczniowie, którzy w najsilniejszy sposób utożsamili się z przydzieloną im rolą, zbliżają się do traumatycznego przeżycia. Choć sam niepewny konsekwencji tak zorganizowanej wycieczki, mężczyzna wierzy, że aby móc jak najpełniej spotkać się z cierpieniem przodków, konieczne jest usunięcie wcześniejszych punktów oparcia, wywołanie dysonansu (by urealnić niewyrażalne) ${ }^{7}$.

Shoshana Felman, rozważając znaczenie i konsekwencje użycia świadectw traumatycznych przeżyć w procesie edukacji kolejnych pokoleń, pyta:

\footnotetext{
${ }^{6}$ Ten sam proces zachodzi w metanarracyjnej warstwie tekstu: autor poprzez stworzenie fikcyjnej opowieści, dla której podstawą są fakty historyczne, umożliwia czytelnikowi zbliżenie się własnym doświadczeniem (emocjami uaktywnionymi w czasie lektury) do dramatycznych wydarzeń z przeszłości. Sylwia Nowak-Bajcar zauważa: „Albahari uznaje, że tradycyjna historiograficzna strategia «opisu śmierci» jest niewystarczająca, fakty prezentowane w ten sposób stają się miejscami pustymi, dlatego konieczne jest ich empatyczne przetworzenie. Powieść stanowi więc przedsięwzięcie zaprezentowania historiografii jako (auto)biografii [pogr. S.N.-B.] (kata i ofiary), a więc «mikrohistorii». Jest to, z jednej strony, próba zmierzenia się z tematem Holokaustu i tematem historii, ale też z drugiej - próba przeniesienia historii na historię jednostkową, próba przełożenia liczb i statystyk na język własnego doświadczenia. Zadaniem Albahariego jest uczłowieczenie historii" (Nowak-Bajcar 2010: 122-123).

${ }^{7}$ Marija Mitrović, analizując utwór Götz i Meyer w kontekście obecności elementów właściwych dla formy dramatycznej, wycieczkę organizowaną przez nauczyciela porównuje do spektaklu teatralnego, którego funkcją ma być właśnie otwarcie możliwości (tak uczniom, jak i narratorowi) utożsamienia się z tragicznym losem rzeczywistych „aktorów” historii, a w rezultacie doświadczenia katharsis (Mitrović 2005: 87-88).
} 
Czy istnieje związek między kryzysem a podstawowymi zadaniami edukacji? (...) Czy trauma powinna być nauczycielką pedagogiki, i czy pedagogika zdołałaby wyjaśnić tajemnicę traumatycznego przeżycia? (Felman 2014: 414).

Felman, wykładowczyni na Uniwersytecie w Yale, organizuje seminarium, podczas którego studenci konfrontują się ze świadectwami różnego rodzaju traumy, w tym artystycznie przetworzonymi (poezja Paula Celana) i bezpośrednio nagranymi świadectwami ocalałych z Holokaustu. Przebieg zajęć doprowadza do kryzysu w grupie, ich uczestnicy stają się naznaczeni cudzym doświadczeniem, co skutkuje tymczasowym wyobcowaniem z aktualnej realności:

Przyjaciele i współlokatorzy tych studentów wysyłali do mnie listy, pisali, że są zainteresowani moim kursem, stając się - cytuję - „przymusowymi słuchaczami” nieformalnych dyskusji nad seminaryjnymi problemami i obsesyjnych monologów uczestników kursu, którzy najwyraźniej nie potrafili o nim zapomnieć (...). W ten sposób zostali oddzieleni, również z własnej woli, od tych, którzy nie przeszli przez podobne doświadczenie. Zachowywali się niczym obłąkani (Felman 2007: 458).

Według Felman, psychiczny kryzys studentów nakłada się na moment identyfikacji z rolą adresata świadectw. Podobne zjawisko zachodzi podczas powieściowej wycieczki. Narrator, oprowadzając jej uczestników po miejscach pamiętających dramatyczne zdarzenia, opowiadając im wyobrażoną, ale prawdopodobną historię ofiar i oprawców, otwiera przed uczniami możliwość opisywanej przez badaczkę identyfikacji. Właśnie te osoby, które najsilniej utożsamiły się z rolą adresata historii o przeszłości, mają stać się nosicielami przetwarzającej teraźniejszość pamięci. Proces ten, ale w swej intensywności skrajny, skutkujący wyobcowaniem i rozpadem spójnej tożsamości, przeszedł sam narrator. Decyzja, by przyjąć na siebie rolę świadka, dezaktualizuje możliwość pełnego scalenia podmiotowości. Biorąc pod uwagę dezintegrację wewnętrznego świata bohatera, która stała się skutkiem próby zrozumienia losu przodków i determinujących go czynów niemieckich podoficerów, decyzję o zachowaniu pamięci tragicznych wydarzeń interpretować można jako porażkę. Z drugiej strony, poprzez próbę skonfrontowania młodego pokolenia z dramatem Zagłady, narrator usiłuje wpłynąć na przyszłą rzeczywistość. Wciągnięty, choć niebezpośrednio, w bieg wydarzeń historycznych, odczuwa ich skutki na własnym życiu. Jednocześnie jednak usiłuje rozbudzić (ukształtować?) wrażliwość 
innych, by mieć poczucie wpływu na zniwelowanie ryzyka powtórzenia tragedii. Wewnętrzny świat narratora podlegający zewnętrznym naciskom wypływa na powierzchnię, w pewnym sensie modelując otoczenie. Refleksja ta znajduje potwierdzenie w słowach Sabiny Giergiel: „W tekstach Albahariego w sposób jednoznaczny ujawnia się sprzężenie zwrotne pomiędzy oddziaływaniem świata na jednostkę a działaniem jednostki, które ma na celu zmianę struktury świata" (Giergiel 2012: 106).

6.

W eseju poświęconym pożytkom płynącym z obcowania z fikcyjnymi światami Mario Vargas Llosa pisze:

Dzięki niej [fikcji - U.P.] jesteśmy czymś więcej i jesteśmy kimś innym, nie przestając jednocześnie być sobą. W niej zatapiamy się i mnożymy nasze wcielenia, przeżywając o wiele więcej, niż moglibyśmy przeżyć, gdybyśmy pozostali więźniami historii, wygnańcami skazanymi na realność (Llosa 1999: 17).

Albahari swoją powieścią ten pogląd potwierdza i pogłębia. Fikcja, otwierająca drogę do innego, cudzego, czasem skrajnie odmiennego doświadczenia, pozwala poszerzyć własne (czytelnika) przeżycia, dając jednak nie tylko przyjemność wcielenia się w żywoty w inny sposób niedoznane, a pożądane, ale i „nieprzyjemność” wysiłku przyjęcia narracji niewygodnych, nieprzystających do projektowanej narracji na temat własnej osoby. Właśnie ta druga, ciemniejsza strona przynosi donioślejsze znaczenie. Działania narratora wskazują na jego wiarę w szkołę wrażliwości, której adepci, w chwili próby, będą skłonni bezmyślność poprzedzić refleksją. Według niego proces ten może realnie wpłynąć na strukturę aktualnej i nadchodzącej rzeczywistości, uchronić przed przyszłymi wcieleniami zła. Pamięć o przeszłości ma stać na końcu drogi wiodącej przez wysiłek kreowania wyobrażeń, a metafizyczny naddatek fikcji zawierać się w jej możliwości udostępnienia cudzego doświadczenia: „I oto wszystko ponownie sprowadza się do samego wyboru pomiędzy zwycięstwem a porażką. Nie istnieje droga pośrednia. (...) Oprócz pamięci, oczywiście, tak jak wyjaśniłem uczniom: dusza, która pamięta, nie może zginąć" (Albahari 2007: 129). 


\section{Literatura}

Albahari D., 2007, Götz i Meyer, przeł. M. Duškov, Toruń.

Albahari D., 2012, David Albahari, Beograd.

Bukwalt M., 2014, My prawda grobów i my złuda istnienia. Obraz zagłady Żydów serbskich w powieści „, Götz i Meyer” Davida Albahariego, „Południowosłowiańskie Zeszyty Naukowe" nr 11, s. 63-77.

Debeljak A., 2014, Balkansko brvno. Eseji o književnosti „jugoslavenske Atlantide”, przeł. J. Pogačnik, Zagreb.

DeKoven Ezrahi S., 2014, Holokaust a zmieniajace się granice sztuki i historii, w: Reprezentacje Holokaustu, wyb. i oprac. J. Jarniewicz, M. Szuster, przeł. M. Michalski, Kraków-Warszawa, s. 163-182.

Felman S., 2014, Nauczanie i kryzys albo meandry edukacji, w: Reprezentacje Holokaustu, wyb. i oprac. J. Jarniewicz, M. Szuster, przeł. M. Lachman, Kraków-Warszawa, s. 343-400.

Giergiel S., 2007, Czy ja to mój bohater? Davida Albahariego gra rolami narracyjnymi, „Pamiętnik Słowiański” z. I, s. 35-54.

Giergiel S., 2012, Ocalić pamięcią. Praktyki pamięci i zapominania we współczesnej prozie postjugosłowiańskiej, Opole, s. 69-122.

Kornhauser J., 2009, Serbska literatura emigracyjna po 1991 roku. Przypadek Davida Albahariego, w: Stowiańskie diaspory. Studia o literaturze emigracyjnej, red. C. Juda, Kraków, s. 133-147.

Llosa M.V.,1999, Prawda kłamstw. Eseje o literaturze, przeł. D. Walasek-Elbanowska, Poznań, s. 5-18.

Mitrović M., 2005, „Gec i Majer” or Situational Education, „Serbian Studies: Journal of the North American Society for Serbian Studies" nr 1, s. 83-93.

Nowak-Bajcar S., 2010, Mapy czasu: serbska proza postmodernistyczna wobec wyzwań epoki, Kraków, s. 91-123.

Nycz R., 2012, Poetyka doświadczenia. Teoria-nowoczesność - literatura, Warszawa.

Ognjenović V., 2007, Cervantesova djeca (zbirka intervjua), Pula, s. 12-17. 